\title{
Comparison of trends in ischaemic heart disease between North Karelia, Finland, and Kaunas, Lithuania, from 1971 to 1987
}

Daiva Rastenyte, Veikko Salomaa, Harri Mustaniemi, Dalia Rasteniene, Regina Grazuleviciene, Zygimantas Cepaitis, Jari Kankaanpää, Kari Kuulasmaa, Jorma Torppa, Juozas Bluzhas, Jaakko Tuomilehto

Institute of

Cardiology, Kaunas,

Lithuania

D Rastenyte

D Rasteniene

R Grazuleviciene

Z Cepaitis

J Bluzhas

Department of

Epidemiology,

National Public

National Public

Helsinki, Finland

V Salomaa

J Kankaanpää

K Kuulasmaa

J Torppa

J Tuomilehto

Central Hospital of

North Karelia,

Joensuu, Finland

H Mustaniemi

Correspondence to:

Dr Veikko Salomaa, National

Public Health Institute,

Department of

Department of

25 A, 6th Floor SF-00510

$25 \mathrm{~A}, 6$ th Floor SF
Helsinki, Finland.

Helsinki, Finland.

11 May 1992.

\section{Abstract}

Objective-To compare the long-term trends in mortality and attack rate of ischaemic heart disease in North Karelia, Finland, and in Kaunas, Lithuania, from 1971 to 1987.

Design-Data on routine mortality statistics were obtained from the Central Statistical Office of Finland and from the Central City Archives of Kaunas. In addition, data from the community based myocardial infarction registers were used. The registers used similar diagnostic criteria and had operated in both areas during the entire study period.

Setting-The province of North Karelia in Finland and the city of Kaunas in Lithuania.

Subjects-The target populations were the people of North Karelia and Kaunas aged 35-64 years.

Main outcome measures-Mortality from ischaemic heart disease and the attack rate of acute myocardial infarction.

Results-In North Karelia mortality from ischaemic heart disease and the attack rate of acute myocardial infarction declined steeply both in men and women. This decline was accompanied by a decrease in total mortality. In Kaunas, both mortality and the attack rate increased in men but remained unchanged in women. In 1985 to 1987, age standardised total mortality per 100000 inhabitants was similar in the two populations in men (1081 (95\% confidence interval (CI) 1013 to 1149), in North Karelia; 1082 (95\% CI 1032 to 1132), in Kaunas). The proportional mortality from ischaemic heart disease was considerably higher in North Karelia (40\%) than in Kaunas $(28 \%)$. In women, age standardised total mortality was lower in North Karelia (350 (95\% CI 312-388)) than in Kaunas (440 (95\% CI 413 to 467)). The proportional mortality from ischaemic heart disease in women was also higher in North Karelia (28\%) than in Kaunas (13\%).
Conclusions-Despite the remarkable decline in the occurrence of ischaemic heart disease, it still remains the most important cause of premature mortality in North Karelia. In Kaunas ischaemic heart disease mortality and attack rate increased in men. Experiences from successful cardiovascular disease prevention programmes in western countries, such as the North Karelia Project, should be exploited to prevent an increasing epidemic of ischaemic heart disease in eastern Europe.

\section{(Br Heart J 1992;68:516-23)}

During the late 1950 s and the early 1960 s several western countries, including Finland, experienced a considerable increase in mortality and morbidity from ischaemic heart disease. ${ }^{12}$ At the end of the 1960 s the province of North Karelia in eastern Finland had the highest ischaemic heart disease mortality ever recorded in the world. ${ }^{3}$ In the early 1970 s mortality from ischaemic heart disease started to decline in North Karelia where this development was enhanced by the community-wide prevention programme launched in $1972 .{ }^{4}$ Similar trends have been described in several western countries. ${ }^{12}$ Despite this decline ischaemic heart disease remains the leading cause of death in developed countries, accounting for nearly half of all deaths. ${ }^{5}$ Furthermore, recent reports have indicated that eastern European countries are now facing an increase in ischaemic heart disease mortality equivalent to that experienced in many western countries in the $1960 \mathrm{~s}^{26}$ Our knowledge of these trends is, however, sparse and mainly based on routine mortality statistics, which are not validated by uniform diagnostic criteria between populations and over time.

Since the early 1970s North Karelia, Finland ${ }^{47}$ and Kaunas, Lithuania, ${ }^{89}$ have had registers for myocardial infarction based on similar methods and data collection procedures. This gave us an opportunity to compare the trends in ischaemic heart disease mortality and attack rates in a western population with those in an eastern European popula- 
Table 1 Populations of North Karelia and Kaunas by age group and sex ${ }^{\star}$

\begin{tabular}{|c|c|c|c|c|c|c|c|}
\hline \multirow[b]{2}{*}{ Sex and year } & \multicolumn{6}{|c|}{ Age groups } & \multirow[b]{2}{*}{ Total } \\
\hline & $35-39$ & $40-44$ & $45-49$ & $50-54$ & $55-59$ & $60-64$ & \\
\hline \multicolumn{8}{|c|}{ North Karelia } \\
\hline $\begin{array}{c}\text { Men: } \\
1973 \\
1978 \\
1986\end{array}$ & $\begin{array}{l}5120 \\
4963 \\
7958\end{array}$ & $\begin{array}{l}5385 \\
5116 \\
5680\end{array}$ & $\begin{array}{l}5420 \\
5311 \\
5015\end{array}$ & $\begin{array}{l}4648 \\
5110 \\
4737\end{array}$ & $\begin{array}{l}4204 \\
4155 \\
4918\end{array}$ & $\begin{array}{l}4097 \\
3607 \\
4103\end{array}$ & $\begin{array}{l}28874 \\
28262 \\
32411\end{array}$ \\
\hline $\begin{array}{c}\text { Women: } \\
1973 \\
1978 \\
1986\end{array}$ & $\begin{array}{l}4706 \\
4614 \\
6621\end{array}$ & $\begin{array}{l}5097 \\
4684 \\
5057\end{array}$ & $\begin{array}{l}5557 \\
5153 \\
4678\end{array}$ & $\begin{array}{l}5269 \\
5434 \\
4616\end{array}$ & $\begin{array}{l}5086 \\
5046 \\
5283\end{array}$ & $\begin{array}{l}5081 \\
4779 \\
5158\end{array}$ & $\begin{array}{l}30796 \\
29649 \\
31413\end{array}$ \\
\hline \multicolumn{8}{|c|}{ Kaunas } \\
\hline $\begin{array}{r}1972 \\
1978 \\
1986\end{array}$ & $\begin{array}{l}11791 \\
14507 \\
13400\end{array}$ & $\begin{array}{l}12445 \\
11800 \\
12996\end{array}$ & $\begin{array}{r}7868 \\
11949 \\
11595\end{array}$ & $\begin{array}{r}5315 \\
9534 \\
10797\end{array}$ & $\begin{array}{l}4674 \\
5954 \\
9776\end{array}$ & $\begin{array}{l}5444 \\
4056 \\
5817\end{array}$ & $\begin{array}{l}47537 \\
57800 \\
64381\end{array}$ \\
\hline $\begin{array}{c}\text { Women: } \\
1972 \\
1978 \\
1986\end{array}$ & $\begin{array}{l}12700 \\
15009 \\
15524\end{array}$ & $\begin{array}{l}12493 \\
13343 \\
14978\end{array}$ & $\begin{array}{l}11112 \\
12865 \\
14176\end{array}$ & $\begin{array}{r}7252 \\
11879 \\
12695\end{array}$ & $\begin{array}{r}7289 \\
8950 \\
11987\end{array}$ & $\begin{array}{r}7966 \\
6709 \\
10178\end{array}$ & $\begin{array}{l}58812 \\
68755 \\
79538\end{array}$ \\
\hline
\end{tabular}

*The mid-year populations of North Karelia were obtained from the Central Statistical Office of Finland. For Kaunas population data were obtained from the Central Statistical Office of Lithuania.

tion. Data from the myocardial infarction registers also meant that routine mortality statistics in these two areas could be validated.

\section{Patients and methods}

North Karelia is the easternmost province of Finland with a population of about 175000 . The area is rural with income mainly from agriculture and forestry. Kaunas is the second largest city of Lithuania with a population of slightly over 400000 . It is an industrial city (mechanical and electronic engineering and food processing) in the central part of the republic. Table 1 shows the population in the two areas according to age and sex.

PROCEDURES FOR THE REGISTRATION OF MYOCARDIAL INFARCTION EVENTS

The myocardial infarction register was started in Kaunas in 1971 and in North Karelia in 1972. Both registers have operated since then. Suspected cases of myocardial infarction were identified through the death certificates and the hospitals treating patients with myocardial infarction in North Karelia and Kaunas. In both areas during the whole study period it was the standard practice to admit to hospital all patients with symptoms who were suspected of having an acute myocardial infarction. In North Karelia, about two thirds of the cases of myocardial infarction are treated in the specialised Central Hospital. The evaluation of all suspected events and the diagnostic classification was done at the Central Hospital by the myocardial infarction register team. The diagnostic categories were assigned by one physician (HM) during the entire study period. In Kaunas most patients with myocardial infarction were treated in the cardiological departments of the four main hospitals where they were admitted through coronary care units. All suspected myocardial infarction events were screened and validated by the central myocardial infarction register team. There was a change in the register team after the first period 1971-1972. During 1971-1972 the Kaunas Myocardial Infarction Register was computerised as a part of the World Health Organisation Heart Attack Register Study. ${ }^{10}$

In Kaunas data for the entire period from 1973 to 1982 were not fully computerised. For practical reasons we decided to estimate the trends in ischaemic heart disease mortality and attack rate of myocardial infarction during three periods: $1971-1972$ (1973-1974 in North Karelia), 1978-1980, and 1985-1987.

Period 1971-1972, 1973-1974

The World Health Organisation Heart Attack Register criteria ${ }^{10}$ were used for the registration of acute myocardial infarction events both in North Karelia and in Kaunas. Kaunas participated in the World Health Organisation International Collaborative Study for Myocardial Infarction Community Registers, but the North Karelia Myocardial Infarction Register started soon after the end of the World Health Organisation study. In both areas the approach to registration of events was prospective ("hot pursuit") in that the collection of information from patients usually started when the patient was admitted to hospital.

\section{Period 1978-1980}

In North Karelia the myocardial infarction register continued during the 1970 s and was based on the same diagnostic criteria and procedures and the hot pursuit technique. During this period Kaunas started to use a "cold pursuit" technique, where events leading to hospital admission were identified mainly from the hospital discharge lists. The diagnostic criteria for and classification of the events remained the same as during the earlier period.

\section{Period 1985-1987}

The World Health Organisation MONICA Project started in the early 1980s. ${ }^{5}$ North Karelia joined the MONICA Myocardial Infarction Register Study in 1982 and Kaunas joined in 1983. Since then both registers have used the diagnostic criteria and the classifica- 
tion of myocardial infarction events recommended by the World Health Organisation MONICA Project. ${ }^{11}$ The MONICA criteria for the classification of the events differ slightly from those of the previous World Health Organisation Heart Attack Register criteria. ${ }^{1213}$ During this period in North Karelia the approach to registration was still hot pursuit whereas Kaunas continued cold pursuit registration.

VALIDATION OF CASES OF SUSPECTED MYOCARDIAL INFARCTION

When a patient died within 28 days of the onset of symptoms it was regarded as a fatal event. Only one event was recorded within a 28 day period.

In North Karelia the completeness of registration was ascertained by regularly reviewing diagnoses on the hospital discharge lists of the whole province in the Central Hospital. Those who died outside the hospital were found by regular reviews of death certificates in the area and the diagnosis was confirmed by cross checking data in the myocardial infarction register against the computerised National Death Certificate Register. The diagnostic data for missing cases were validated before such cases were added to the myocardial infarction register. The consistency of the diagnostic classification of the registered cases during 1972-1977 was evaluated in a subsample. The reclassification of the events showed a $94 \%$ agreement. ${ }^{7}$ In Kaunas the completeness of the registration was ascertained by a regular review of death certificates in the area and of the hospital discharge lists for hospitals in the city. Since 1978 every twentieth case has been recoded by two independent coders to establish the reliability of event registration.

\section{DIAGNOSTIC CATEGORIES}

To reduce the influence of changes in diagnostic criteria over time and the possible influence of the change from a hot pursuit to a cold pursuit technique in Kaunas, only cases in the diagnostic category "definite myocardial infarction" and fatal cases with diagnostic categories "possible myocardial infarction" or "insufficient data" were included in the analyses. $^{1011}$ Definitions of these categories during the different study periods are given below.

\section{In 1971-1972, 1973-1974, and 1978-1980 10}

Definite myocardial infarction-Typical electrocardiogram or equivocal electrocardiogram wih raised enzymes and history of typical or atypical pain or a typical history of pain with raised enzymes; or positive findings at necropsy.

Possible myocardial infarction-Fatal cases whether sudden or not where there was no good clinical or necropsy evidence for another cause of death with a history of typical or atypical pain, or of chronic ischaemic heart disease or necropsy evidence of chronic ischaemic heart disease.

Insufficient data-Fatal cases with no necropsy, no history of pain, no previous history of chronic ischaemic heart disease, and no other diagnosis.

\section{In 1985-1987"1}

The diagnostic categories differed only slightly from the previous study periods. The diagnostic criteria were more strictly standardised and symptoms were described in more detail than previously. Serial Minnesota coding was introduced for the classification of electrocardiographic changes.

Definite myocardial infarction-Definite electrocardiogram; or probable electrocardiogram with abnormal enzyme concentrations and with symptoms that are typical or atypical or inadequately described; or ischaemic or noncodable electrocardiogram or electrocardiogram not available with abnormal enzyme concentrations and typical symptoms; or fatal cases with positive findings at necropsy.

Possible myocardial infarction or coronary death-Fatal cases whether sudden or not where there is no good evidence for another cause of death clinically or at necropsy, with symptoms typical or atypical or inadequately described, or without typical or atypical or inadequately described symptoms but with evidence of chronic ischaemic heart disease at necropsy, or with a good history of chronic ischaemic heart disease.

Insufficient data-Fatal cases with no necropsy, no history of typical or atypical or inadequately described symptoms, no previous history of chronic ischaemic heart disease, and no other diagnosis.

Standard 12 lead electrocardiograms were recorded in hospital cases in both areas during the whole study period. In the beginning electrocardiograms were classified on the basis of the Minnesota code according to the recommendations of the World Health Organisation Register Study. ${ }^{14}$ After they joined the MONICA project both areas used serial Minnesota coding.

In both areas before the World Health Organisation MONICA Project cardiac enzyme classification was based on aspartate aminotransferase and lactate dehydrogenase determinations during the first time period: a 1.5 fold rise was categorised as "definite enzymes" Thus the criteria for "definite enzymes" in North Karelia and Kaunas were stricter than in the World Health Organisation Register Study. According to the protocol of that $s t u d y^{10}$ a rise above normal reference range for the laboratory was categorised as "definite enzymes". Since the beginning of the MONICA project a twofold rise has been required in both areas. Plasma concentrations of creatine kinase and its $M B$ isoenzyme have been used in North Karelia since 1982 in 95$100 \%$ of cases. In Kaunas measurements of creatine kinase and its $\mathrm{MB}$ isoenzyme have been available since 1979 in about $50 \%$ of cases. In the remainder aspartate aminotransferase and lactate dehydrogenase were used.

\section{ROUTINE MORTALITY STATISTICS}

The data on death rates in North Karelia from 1971 to 1987 were obtained from the Central 
Statistical Office of Finland (official mortality statistics). The diagnoses made by local physicians on the individual death certificates are reviewed in this office by a nosologist according to the guidelines of the International Classification of Diseases (ICD). The ICD 8th revision (ICD-8) was used in Finland until 1986 and ICD-9 since the beginning of 1987 . In Kaunas no official mortality statistics were available but all the death certificates from 1971 to 1974 and from 1978 to 1987 were obtained from Central City Archives and computerised records were kept by the Kaunas Research Institute of Cardiology. The death certificates are filled in and coded by the physician certifying the death. Diagnoses on the death certificate are not checked up or recoded. ICD-8 was used until 1977 and ICD-9 since the beginning of 1978 in most hospitals and outpatient departments in Kaunas. Death certificates coded according to ICD-8 in 19781980 were recoded according to ICD-9 by the staff of the register group.

\section{NECROPSY RATE}

In North Karelia necropsy was performed on $27 \%$ of those who died of ischaemic heart disease in 1973-74 and 55\% in 1985-1987. Whereas in Kaunas the frequency of necropsy decreased from $72 \%$ in $1971-1972$ to $60 \%$ in 1985-1987.

\section{STATISTICAL METHODS}

The "attack rate" of acute myocardial infarction in our present study refers to all symptomatic events of acute myocardial infarction, whether first or recurrent. It thus includes fatal cases in the diagnostic categories of "definite myocardial infarction", "possible myocardial infarction", or "insufficient data", and nonfatal cases with "definite myocardial infarction". Age standardisation was performed by the direct method in five-year age groups and according to the World Standard Population. ${ }^{15}$ Confidence intervals for the rates were calculated assuming the Poisson variation of the number of events within the age groups. Trends in attack rate and mortality were cal- culated by linear regression on logarithms of the annual rates. The trend (percentage of a continuous change per year) was reported as the regression coefficient multiplied by 100 .

p Values $<0.05$ were regarded as statistically significant. All the reported $p$ values are twotailed. The equality of the trends in slopes between Kaunas and North Karelia was not tested because of the apparent ambiguity in the interpretation of equality of trends when the actual mortality rates are very different. However, when one trend is significantly negative and the other one significantly positive there is no such ambiguity.

\section{Results}

Routine mortality statistics showed that mortality from ischaemic heart disease in North Karelian men aged 35-64 years decreased significantly from 1971 to 1987 (fig 1) by $2.3 \%$ per year $(95 \%$ CI -2.9 to $-1.6, p=0.0001$ according to regression analy is)). In Kaunas mortality increased by $2.4 \%$ per year $(95 \%$ CI +1.3 to $+3.6, p=0.0005)$. In North Karelia mortality from ischaemic heart disease in women also declined significantly (fig 1) by $2 \cdot 2 \% /$ year $(95 \%$ CI -4.0 to $-0.4, \mathrm{p}=0.02)$. In Kaunas mortality statistics based on death certificates showed a small (NS) increase in mortality from ischaemic heart disease $(0.6 \%$ per year $(95 \% \mathrm{CI}-1.5$ to $+2 \cdot 7, \mathrm{p}=0.54)$ by regression analysis.

Proportional mortality from ischaemic heart disease was higher in North Karelia than in Kaunas (table 2). During the early 1970s mortality from all causes in men was significantly higher in North Karelia than in Kaunas. This difference later disappeared. During the period 1985-1987 total mortality among men was similar for the two areas, but the proportion of all deaths caused by ischaemic heart disease was $40 \%$ in North Karelia but only $28 \%$ in Kaunas. In women total mortality was lower in North Karelia than in Kaunas, but the proportion of total mortality caused by ischaemic heart disease was clearly higher in North
Figure 1 Trends in age standardised mortality (per 100000 population) from ischaemic heart disease (expressed in logarithmic scale) during 1971 to 1987 according to the routine mortality statistics in men and women aged 35-64 years in North Karelia and Kaunas. Annual percentage changes based on linear regression (95\% confidence interval) are $-2 \cdot 3(-2 \cdot 9$ to $-1 \cdot 6$ $p=0.0001)$ and $+2 \cdot 4$ $(+1 \cdot 3$ to $+3 \cdot 6, p=$ $0.0005)$ in men and $-2 \cdot 2$ $(-4.0$ to $-0.4, p=$ $0.02)$ and $+0.6(-1.5$ to $+2 \cdot 7, p=0.54$ ) in women in North Karelia and Kaunas respectively.
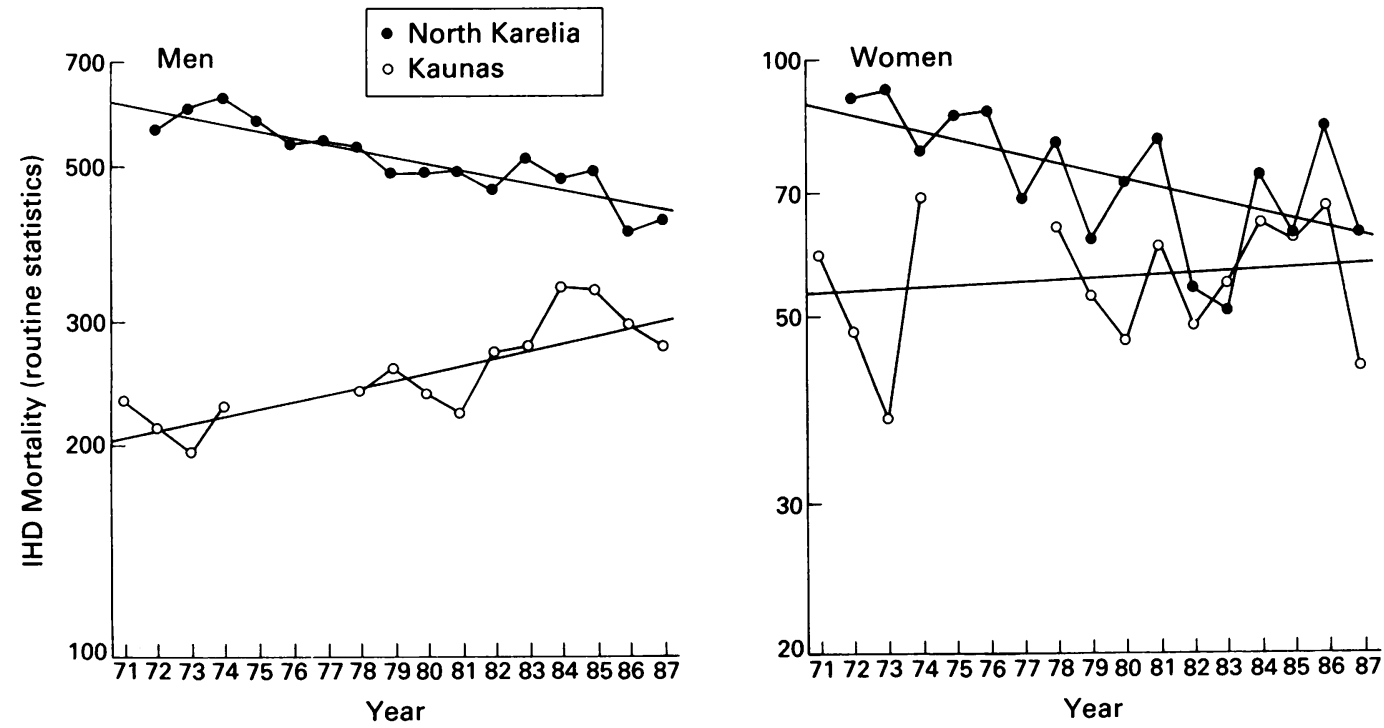
Table 2 Age standardised ischaemic heart disease, cardiovascular disease, and total mortality (95\% confidence interval) and the proportion of ischaemic heart disease mortality from total mortality (\%) in men and women aged 35-64 years in North Karelia and Kaunas. Rates are based on the routine mortality statistics and are expressed as a mean of each two or three year period

\begin{tabular}{|c|c|c|c|c|}
\hline \multirow[b]{2}{*}{$\begin{array}{l}\text { Age, sex, and } \\
\text { period }\end{array}$} & \multicolumn{3}{|c|}{ Annual mortality rate per 100000 population } & \multirow[b]{2}{*}{$\begin{array}{l}\text { Proportional mortality from } \\
\text { ischaemic heart disease }(\%)\end{array}$} \\
\hline & $\begin{array}{l}\text { Ischaemic heart } \\
\text { disease }(95 \% \text { CI) }\end{array}$ & $\begin{array}{l}\text { Cardiovascular disease } \\
\text { (95\% CI) }\end{array}$ & $\begin{array}{l}\text { All causes } \\
(95 \% C I)\end{array}$ & \\
\hline \multicolumn{5}{|c|}{ North Karelia } \\
\hline Men: & \multirow{4}{*}{$\begin{array}{l}610 \\
(546 \text { to } 674) \\
503 \\
(455 \text { to } 551) \\
437 \\
(394 \text { to } 480)\end{array}$} & & & \\
\hline 1973-1974 & & $\begin{array}{l}800 \\
(727 \text { to } 873)\end{array}$ & \multirow{3}{*}{$\begin{array}{l}1380 \\
(1280 \text { to } 1480) \\
1256 \\
(1172 \text { to } 1340) \\
1081 \\
(1013 \text { to } 1149)\end{array}$} & 44 \\
\hline $1978-1980$ & & $\begin{array}{l}663 \\
(608 \text { to } 718)\end{array}$ & & 40 \\
\hline $1985-1987$ & & $\begin{array}{l}573 \\
(524 \text { to } 622)\end{array}$ & & 40 \\
\hline \multicolumn{5}{|l|}{ Women: } \\
\hline 1973-1974 & \multirow{3}{*}{$\begin{array}{l}85 \\
(64 \text { to } 106) \\
71 \\
(55 \text { to } 87) \\
70 \\
(54 \text { to } 86)\end{array}$} & \multirow{3}{*}{$\begin{array}{l}182 \\
(150 \text { to } 214) \\
148 \\
(124 \text { to } 172) \\
125 \\
(103 \text { to } 147)\end{array}$} & \multirow{3}{*}{$\begin{array}{l}415 \\
(365 \text { to } 465) \\
376 \\
(336 \text { to } 416) \\
350 \\
(312 \text { to } 388)\end{array}$} & 20 \\
\hline $1978-1980$ & & & & 19 \\
\hline $1985-1987$ & & & & 20 \\
\hline \multicolumn{5}{|c|}{ Kaunas } \\
\hline $\begin{array}{l}\text { Men: } \\
1971-1972\end{array}$ & \multirow{4}{*}{$\begin{array}{l}222 \\
(189 \text { to } 255) \\
245 \\
(218 \text { to } 272) \\
303 \\
(276 \text { to } 330)\end{array}$} & & \multirow{5}{*}{$\begin{array}{l}1075 \\
(1003 \text { to } 1147) \\
1221 \\
(1162 \text { to } 1280) \\
1082 \\
(1032 \text { to } 1132)\end{array}$} & \\
\hline & & $(305$ to 389$)$ & & 21 \\
\hline $1978-1980$ & & $\begin{array}{l}367 \\
(334 \text { to } 400)\end{array}$ & & 20 \\
\hline $1985-1987$ & & $\begin{array}{l}436 \\
(404 \text { to } 468)\end{array}$ & & 28 \\
\hline \multicolumn{4}{|l|}{ Women: } & \\
\hline $1971-1972$ & \multirow{3}{*}{$\begin{array}{l}53 \\
(40 \text { to } 66) \\
55 \\
(44 \text { to } 66) \\
58 \\
(48 \text { to } 68)\end{array}$} & \multirow{3}{*}{$\begin{array}{l}133 \\
(111 \text { to } 155) \\
126 \\
(109 \text { to } 143) \\
134 \\
(119 \text { to } 149)\end{array}$} & \multirow{3}{*}{$\begin{array}{l}472 \\
(431 \text { to } 513) \\
475 \\
(444 \text { to } 506) \\
440 \\
(413 \text { to } 467)\end{array}$} & 11 \\
\hline $1978-1980$ & & & & 11 \\
\hline $1985-1987$ & & & & 13 \\
\hline
\end{tabular}

Karelia (table 2). Among men the proportion of mortality from all cardiovascular diseases caused by ischaemic heart disease was constant in North Karelia (76\%) and increased in Kaunas from $64 \%$ to $69 \%$. Among women the proportion was around $50 \%$ in North Karelia and around $42 \%$ in Kaunas.

The attack rate of myocardial infarction decreased steeply $(2.6 \%$ per year, $95 \%$ CI -3.6 to $-1.5, p=0.0009$ ) among North Karelian men aged 35-64 years during the study period (fig 2, table 3). In Kaunas the attack rate increased by $1.0 \%$ a year $(95 \% \mathrm{CI}$ $+0 \cdot 2$ to $+1 \cdot 9, \mathrm{p}=0.02)$. The regression based decline in the attack rate of myocardial infarction from 1973 to 1987 was $44 \%$ in North Karelia and the increase in Kaunas was $17 \%$. The decrease in the attack rate in North Karelia was caused by a change in the younger age groups (35-54 years) whereas in Kaunas the increase mainly occurred among younger men (table 3). In women the slight decreases in the attack rate of myocardial infarction in both areas were not statistically significant (table 3). The regression based decrease in North Karelian women was $0.6 \%$ per year $(95 \%$ CI -2.0 to $+0.9, \mathrm{p}=0.38$ ) and in Kaunas $1.1 \%$ per year $(95 \% \mathrm{CI}-4.0$ to $+1.85, \mathrm{p}=0.40)$. Mortality from myocardial infarction validated against the myocardial infarction register showed a downward trend in North Karelia whereas in Kaunas there was no significant trend (fig 3, table 4). The regression based decrease in North Karelian men was $2.6 \%$ per year $(95 \% \mathrm{CI}-3.5$ to $-1.7, \mathrm{p}=0.0004)$ and in men in Kaunas there was an increase of $0.9 \%$ per year $(95 \% \mathrm{CI}-0.1$ to $+1.9, \mathrm{p}=0.07)$. Among women both in North Karelia and Kaunas the data from the myocardial infarction register suggested a decline (NS). The regression based decrease in North Karelian women was $1 \cdot 7 \%$ per year $(95 \% \mathrm{CI}-3 \cdot 4$ to $+0 \cdot 1, \mathrm{p}=$ $0.06)$ and in Kaunas $2.6 \%$ per year $(95 \%$ CI $-6 \cdot 3$ to $+1 \cdot 2, \mathrm{p}=0 \cdot 15)$.

Although in men the differences in the attack rate and mortality of myocardial infarction between the two areas decreased over time, the attack rate of myocardial infarction during 1985-1987 remained approximately twice as high in North Karelia as in Kaunas (table 3). In 1985-1987 mortality from myocardial infarction according to the myocardial infarction register data was $68 \%$ higher in men and $58 \%$ higher in women in North Karelia than in Kaunas (table 4).

\section{Discussion}

Our study assessed long-term trends in the occurrence of ischaemic heart disease from routine mortality statistics and myocardial infarction registration in two countries with different genetic backgrounds and different living conditions. Few registries can provide such long-term data, and of these Kaunas is the only one in eastern Europe, in an area where mortality from ischaemic heart disease is still increasing. During the study period, however, several changes may have affected the comparability of the results over time and between the two centres. For routine mortality statistics, one is the change from ICD-8 to ICD-9. In North Karelia this occurred at the beginning of 1987 . Hence only the last year could be affected. Even in that year, however, ischaemic heart disease mortality both in men and women was well in line with the previous years and the change in the ICD revision did not substantially affect the mortality trend. Furthermore, 
Figure 2 Trends in age standardised attack rates (per 100000 population) of ischaemic heart disease (expressed in logarithmic scale) during 1971 to 1987 according to data from the myocardial infarction register in men and women aged 35-64 years in North Karelia and Kaunas. Annual percentage changes based on linear regression ( $95 \%$ confidence interval) are $-2.6(-3.6$ to -1.5 $p=0.0009)$ and +1.0

$(+0.2$ to +1.9

$p=0.02)$ in men and

$-0.6(-2.0$ to +0.9

$p=0.38)$ and $-1 \cdot 1$

$(-4.0$ to +1.85 ,

$p=0.40$ ) in women in

North Karelia and

Kaunas respectively.

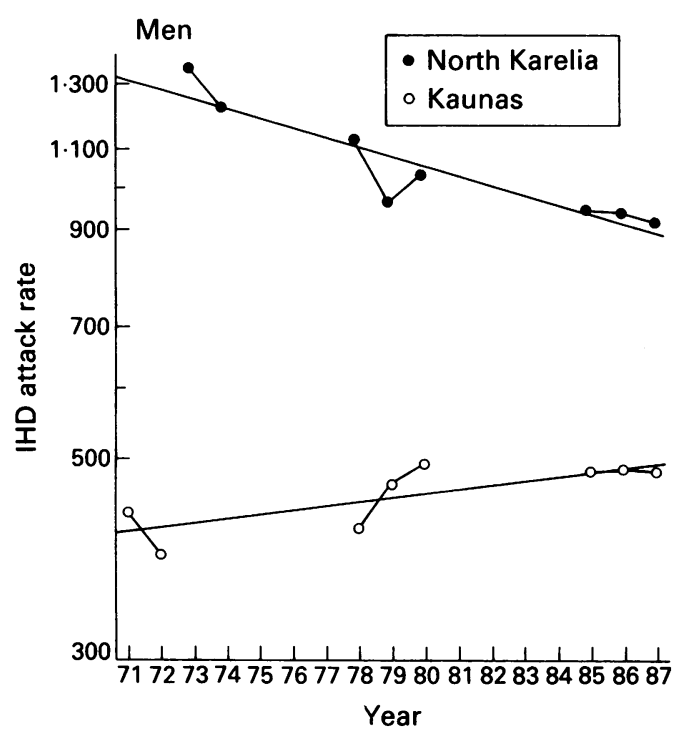

in most industrialised countries the change from ICD-8 to ICD-9 caused only a small degree of discontinuity. ${ }^{16}$ Thus the change of ICD revision in 1978 in Kaunas seems unlikely to have had much effect. The methods used by the myocardial infarction registers were standardised according to common criteria in both areas. In addition to the fatal cases, only definite myocardial infarctions in living patients were included in the present analyses to enhance the comparability of findings. It has been suggested that use of these categories is the best basis for comparisons between the centres using different methods, such as the hot pursuit and cold pursuit techniques of registration. ${ }^{17}$ On the other hand, workers in Auckland, New Zealand, reported that only $82 \%$ of cases, classified as "definite myocardial infarctions"

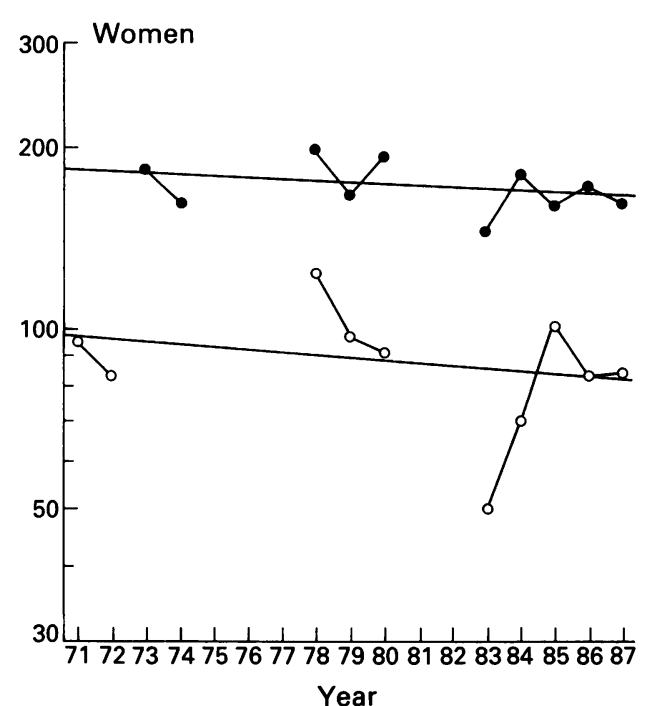

according to the old World Health Organisation criteria, remained as "definite myocardial infarctions" when the MONICA criteria were applied. ${ }^{18}$ This could lead to spurious decline in the attack rates both in North Karelia and Kaunas in the early 1980s. However, the old register criteria of the World Health Organisation relied on some subjective assessment, especially of electrocardiographic findings. ${ }^{10}$ Therefore it is not clear whether the results of the Auckland group are repeatable elsewhere. Also the fact that criteria for "definite abnormal cardiac enzymes" were stricter both in North Karelia and Kaunas than in the World Health Organisation register in general, tends to reduce the possible differences between the two criteria. The introduction of more sensitive cardiac enzymes, creatine kinase and its MB

Table 3 Number of cases and age standardised attack rates of acute MI (95\% confidence interval) in men and women aged $35-64$ years in North Karelia and Kaunas by age. Rates are based on the data of the myocardial infarction registers and expressed as a mean of each two or three year period

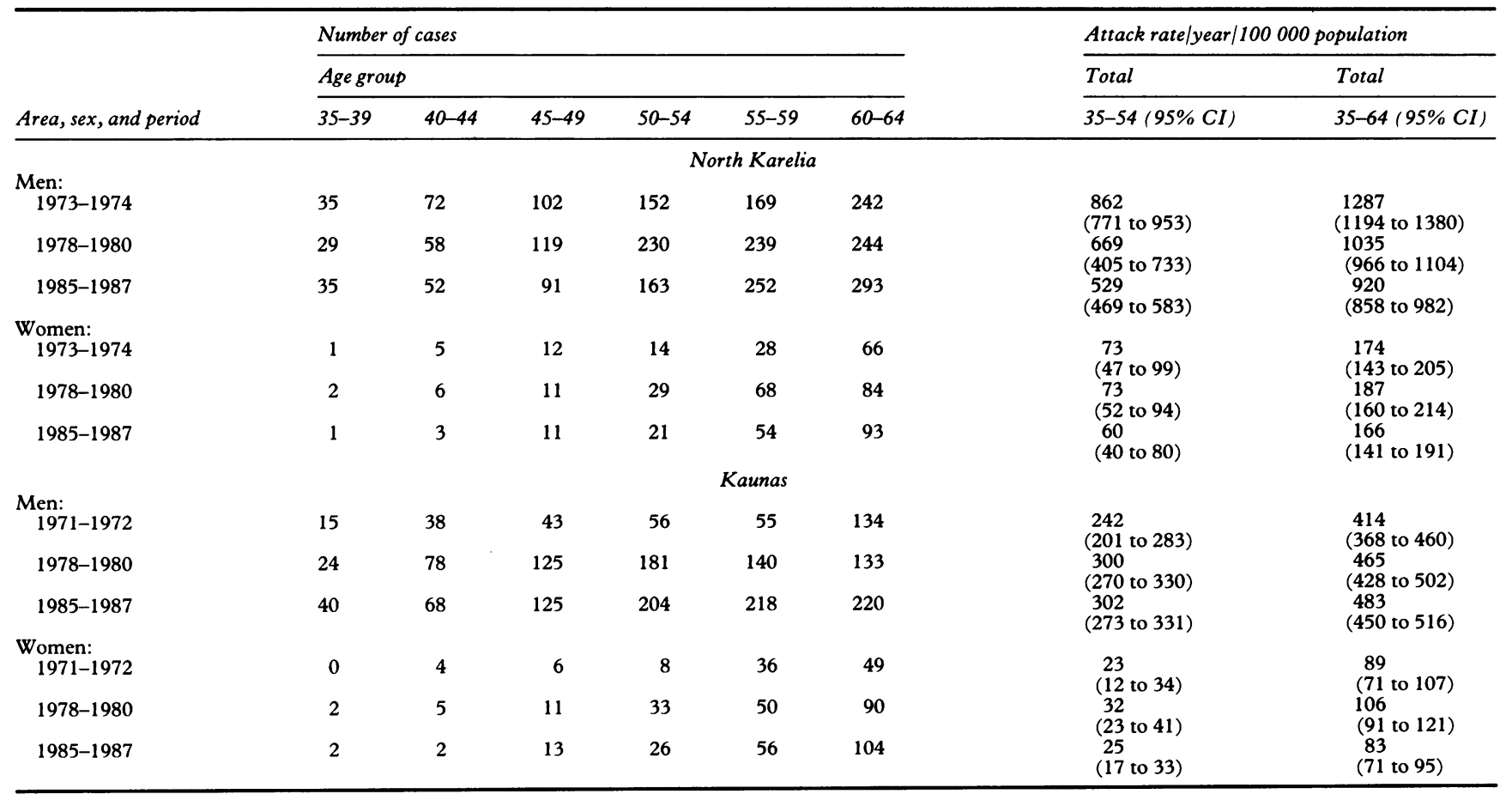


Figure 3 Trends in age standardised mortality (per 100000 population) from ischaemic heart disease (expressed in logarithmic scale) during 1971 to 1987 according to data from the myocardial infarction register in men and women aged 35-64 years in North Karelia and Kaunas. Annual percentage changes based on linear regression (95\% confidence interval) are $-2 \cdot 6(-3.5$ to $-1 \cdot 7$, $p=0.0004)$ and +0.9 $(-0.1$ to $+1 \cdot 9$, $p=0.07)$ in men and $-1.7(-3.4$ to +0.1 , $p=0.06)$ and -2.6 $(-6 \cdot 3$ to $+1 \cdot 2$, $p=0.15)$ in women in North Karelia and Kaunas, respectively.

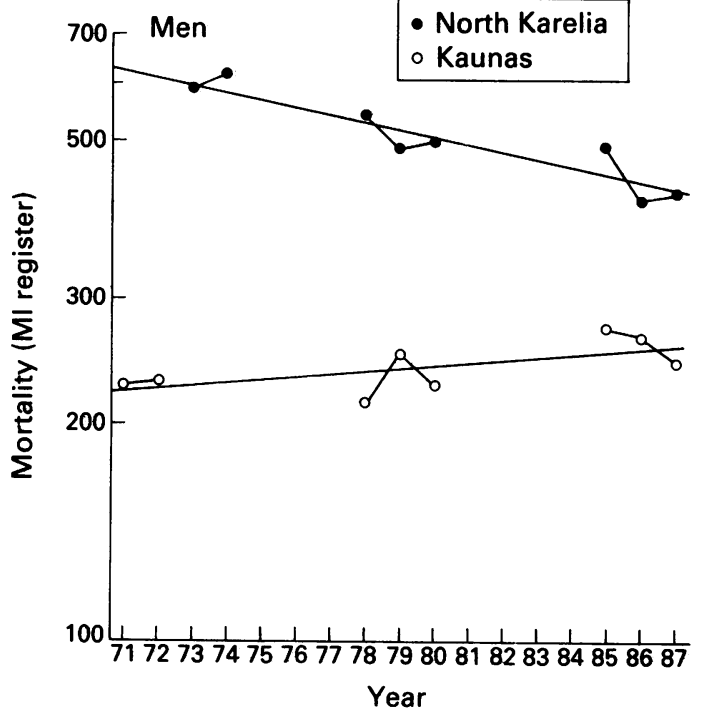

isoenzyme, has probably also had some effect on the trends. The Minnesota Heart Survey investigators showed that the addition of these enzymes to the diagnostic criteria increases the rate of definite myocardial infarctions. ${ }^{19}$ This has probably lessened the decline of the attack rates in North Karelia and may have contributed to the increase in men in Kaunas, although creatine kinase and its $\mathrm{MB}$ isoenzyme were measured in only about $50 \%$ of the cases in Kaunas. On the other hand, the cutpoint for "definite abnormal enzymes" was raised from an increase of 1.5 -fold to 2 -fold at the start of the MONICA project, which would counter these effects.

In fatal cases the high necropsy rate in Kaunas increases the diagnostic accuracy and reduces the influence of other changes in meth-

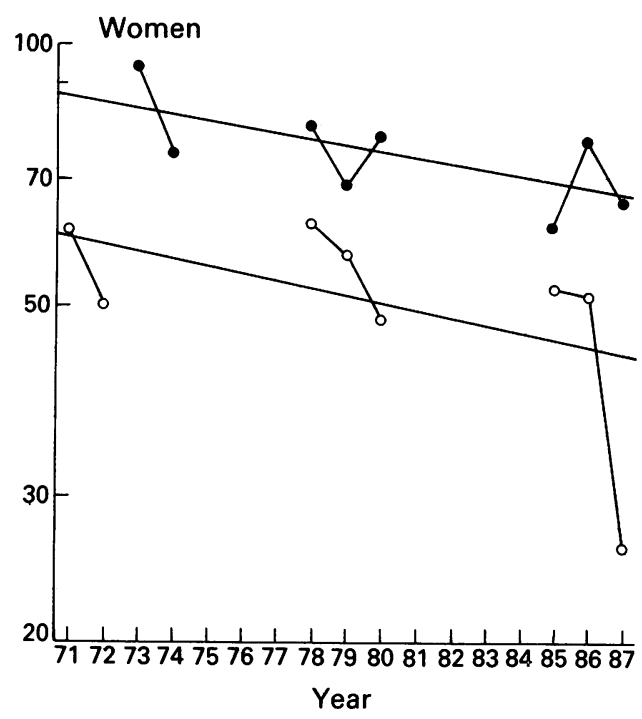

ods. At the end of the observation period the necropsy rates were similarly high in both areas but at the beginning of the 1970s the necropsy rate in North Karelia was considerably lower than that in Kaunas. The necropsies in North Karelia were, however, focused on the cases where there was insufficient clinical information. ${ }^{20}$ Thus the different necropsy rates at the start of the study are unlikely to have caused a substantial difference in the diagnostic classification between the areas.

Despite several potential pitfalls, which are inevitable in this kind of long-term comparison, we believe that our study gives a representative picture of the trends in the mortality and attack rate of myocardial infarction in both areas. The study confirmed that for myocardial infarction in North Karelia there was a con-

Table 4 Number of cases and age standardised mortality from ischaemic heart disease (95\% confidence interval) in men and women aged 35-64 years in North Karelia and Kaunas by age. Rates are based on the data of the myocardial infarction registers and expressed as a mean of each two or three year period

\begin{tabular}{|c|c|c|c|c|c|c|c|c|}
\hline \multirow[b]{3}{*}{ Area, sex, and period } & \multicolumn{6}{|c|}{ Number of cases } & \multicolumn{2}{|c|}{ Mortality rate/year/100 000 population } \\
\hline & \multicolumn{6}{|c|}{ Age group } & \multirow{2}{*}{$\frac{\text { Total }}{35-54(95 \% C I)}$} & \multirow{2}{*}{$\begin{array}{l}\text { Total } \\
35-64(95 \% C I)\end{array}$} \\
\hline & $35-39$ & $40-44$ & $45-49$ & $50-54$ & $55-59$ & $60-64$ & & \\
\hline \multicolumn{9}{|c|}{ North Karelia } \\
\hline $\begin{array}{l}\text { Men: } \\
1973-1974\end{array}$ & 8 & 30 & 42 & 67 & 81 & 138 & \multirow{3}{*}{$\begin{array}{l}350 \\
(292 \text { to } 408) \\
290 \\
(248 \text { to } 332) \\
230 \\
(192 \text { to } 268)\end{array}$} & \multirow{3}{*}{$\begin{array}{l}604 \\
(541 \text { to } 667) \\
509 \\
(461 \text { to } 557) \\
438 \\
(395 \text { to } 481)\end{array}$} \\
\hline $1978-1980$ & 11 & 23 & 45 & 112 & 122 & 140 & & \\
\hline $1985-1987$ & 13 & 26 & 35 & 75 & 120 & 154 & & \\
\hline \multicolumn{9}{|l|}{ Women: } \\
\hline 1973-1974 & 0 & 2 & 3 & 6 & 17 & 35 & \multirow{3}{*}{$\begin{array}{l}25 \\
(10 \text { to } 40) \\
25 \\
(13 \text { to } 38) \\
29 \\
(15 \text { to } 43)\end{array}$} & \multirow{3}{*}{$\begin{array}{l}84 \\
(63 \text { to } 105) \\
76 \\
(59 \text { to } 93) \\
68 \\
(52 \text { to } 84)\end{array}$} \\
\hline $1978-1980$ & 0 & 2 & 3 & 12 & 27 & 38 & & \\
\hline $1985-1987$ & 1 & 2 & 4 & 11 & 17 & 39 & & \\
\hline \multicolumn{9}{|c|}{ Kaunas } \\
\hline $\begin{array}{l}\text { Men: } \\
\quad 1971-1972\end{array}$ & 4 & 14 & 19 & 26 & 33 & 89 & \multirow{3}{*}{$\begin{array}{l}104 \\
(77 \text { to } 131) \\
130 \\
(110 \text { to } 150) \\
143 \\
(123 \text { to } 163)\end{array}$} & \multirow{3}{*}{$\begin{array}{l}228 \\
(194 \text { to } 262) \\
232 \\
(205 \text { to } 259) \\
261 \\
(236 \text { to } 286)\end{array}$} \\
\hline $1978-1980$ & 9 & 32 & 56 & 79 & 72 & 79 & & \\
\hline 1985-1987 & 17 & 22 & 65 & 102 & 123 & 136 & & \\
\hline $\begin{array}{l}\text { Women: } \\
\text { 1971-1972 }\end{array}$ & 0 & 3 & 3 & 1 & 27 & 31 & \multirow{3}{*}{$\begin{array}{l}8 \\
(12 \text { to } 14) \\
13 \\
(7 \text { to } 19) \\
11 \\
(6 \text { to } 16)\end{array}$} & \multirow{3}{*}{$\begin{array}{l}55 \\
(41 \text { to } 69) \\
57 \\
(46 \text { to } 68) \\
43 \\
(35 \text { to } 51)\end{array}$} \\
\hline $1978-1980$ & 0 & 2 & 4 & 14 & 25 & 55 & & \\
\hline $1985-1987$ & 2 & 1 & 7 & 8 & 28 & 59 & & \\
\hline
\end{tabular}


siderable decline in mortality and attack rate from the beginning of the 1970s till 1987 . Similar declines in ischaemic heart disease mortality have been reported in many western countries, ${ }^{121}$ but the trends in attack rates or hospital admissions are not so well established..$^{22}$ The decline in ischaemic heart disease mortality in North Karelia was accompanied by similar decline in cardiovascular disease mortality and in total mortality. Thus no other cause of death has replaced ischaemic heart disease in men and women of this age group. On the other hand, the results suggest that in men in Kaunas ischaemic heart disease mortality is increasing, as it is in many other eastern European countries. ${ }^{1223}$ Nor was there a decline in total mortality in men in Kaunas. The levels of conventional risk factors for ischaemic heart disease in many eastern European populations have been increasing and at the present they are higher than in most other European populations. ${ }^{62425}$

In North Karelia mortality estimates based on routine mortality statistics and on the myocardial infarction register were similar. In Kaunas routine mortality statistics based on death certificates showed a $41 \%$ increase in ischaemic heart disease mortality in men aged 35-64 years during 1971 to 1987 , whereas the myocardial infarction register data showed an increase of only $17 \%$. In women there was a similar discrepancy: an increase of $10 \%$ based on routine mortality statistics but a decrease of $44 \%$ based on the myocardial infarction register. This suggests that routine statistics may have exaggerated the increase in mortality from ischaemic heart disease in Kaunas. This suggestion accords with the increase in proportional mortality from ischaemic heart disease in Kaunas.

Despite the remarkable decline in mortality from ischaemic heart disease in North Karelia it still remains considerably higher than that in Kaunas. This emphasises the need to continue preventive and treatment efforts for ischaemic heart disease in Finland. In Kaunas the continuing increase, particularly among young men, is alarming and resembles the situation in many western countries in the early $1960 \mathrm{~s}$. The experiences of successful prevention programmes, such as the North Karelia project, should be exploited to prevent the increasing epidemic of ischaemic heart disease in eastern European countries.

1 Thom TJ. International mortality from heart disease rates and trends. Int J Epidemiol 1989;18(suppl 1):20-8.

2 Uemura $K$, Pisa $Z$. Trends in coronary heart disease mortality in industrialized countries since 1950. World Health Stat $Q$ 1988;41:155-78.

3 Keys A, Aravanis C, Blackburn HW, et al. Epidemiological studies related to coronary heart disease. Characteristics of men aged 40-59 in seven countries. Acta Med Scand 1967; 460(suppl): 1-392.

4 Puska $\mathrm{P}$, Tuomilehto J, Salonen J, et al. Community control of cardiovascular diseases - the North Karelia Project. Evaluation of a comprehensive community programme for control of cardiovascular diseases in 1972-1977 in North Karelia. WHO/EURO, Monograph Series, Copenhagen, 1981.

5 WHO MONICA Project/Bothig S. WHO MONICA project: objectives and design. Int J Epidemiol 1989;18 (suppl 1):29-37.

6 Deev AD, Oganov RG. Trends and determinants of cardiovascular mortality in the Soviet Union. Int J Epidemio 1989;18(suppl 1):137-44

7 Puska P, Mustaniemi $H$. Incidence and presentation of myocardial infarction in North Karelia, Finland. Acta Med Scand 1975;197:211-6.

8 Yanushkevichus ZL, Bluzhas IN, Stalioraityte EI et al. Acute myocardial infarction register: feasibility of improving diagnosis and clarifying the nature of sudden death/sudden cardiac death/2nd USA-USSR Joint Symposium. Indianapolis, Indiana, 1979; NIH publication no 81-2101. 1980:49-60.

9 Bluzhas J. (ed) Ischaemic heart disease. Diagnosis, clinical manifestations and prevention. Kaunas, Lithuanian SSR, USSR. Lithuanian Medicine. Vilnius: Mokslas, 1987; $1-160$.

10 WHO Regional Office for Europe. Public Health Papers No 5. Myocardial Infarction Community Register. Copenhagen: World Health Organization, 1976.

11 World Health Organization, Geneva 1986: MONICA Manual CVD/MNC/Version 1.1.

12 WHO MONICA Project/Tuomilehto J, Kuulasmaa K, WHO Monica Project: assessing CHD mortality and morbidity. Int J Epidemiol 1989;18(suppl 1):38-45.

13 Martin CA, Hobbs MST, Armstrong BK. Measuring the incidence of acute myocardial infarction: the problem of possible acute myocardial infarction. Acta Med Scand possible acute myocar

14 WHO Regional Office for Europe. Ischaemic heart disease registers. World Health Organization. Geneva: 1970 45-8.

15 Waterhouse J, Muir C, Correo P, Powell J, eds. Cancer incidence in five continents, vol II (IARC Scientific Publications No. 15) Lyon: International Agency for Publications No. 15) Lyon:
Research on Cancer, 1976.

16 Uemura K, Pisa Z. Recent trends in cardiovascular disease mortality in 27 industrialized countries. World Health Stat $Q$ 1985;38:142-62.

17 Beaglehold R, Dobson A, Hobbs $M$, et al. Comparison of event rates among three MONICA centres. Acta Med Scand 1988, (suppl 728):53-9.

18 Beaglehole R, Stewart AW, Butler M. Comparability of old and new World Health Organization criteria for definite myocardial infarction. Int J Epidemiol 1987;16:373-6.

19 Burke GL, Edlavitch SA, Crow RS. The effects of diagnostic criteria on trends in coronary heart disease morbidity: The Minnesota Heart Survey. J Clin Epidemiol 1989;42:17-24.

20 Tuomilehto J, Arstila M, Kaarsalo E, et al. Acute Myocardial Infarction in Finland-Baseline Data from the FINMONICA Coronary Register In 1983-1985. Eur Heart J 1992;13:577-87.

21 Martin CA, Hobbs MST, Armstrong BK, de Klerk NH. Trends in the incidence of myocardial infarction in Western Australia between 1971 and 1982. Am J Epidemiol 1989;129:655-68.

22 Higgins $M$, Thom $T$. Trends in CHD in the United States. Int J Epidemiol 1989;18(suppl 1):58-66.

23 Rywik S, Wagrowska H, Broda G, et al. Epidemiology of Cardiovascular Diseases in Warsaw Pol-MONICA Area. Int J Epidemiol 1989;18(suppl 1):129-36.

24 Cepaitis Z, Domarkiene S, Kalinina A, et al. Epidemiology of risk factors for cardiovascular and other major noncommunicable diseases. Collaborative Study between the USSR and Finland (SOVFIN) in the area "Epidemiology and prevention of cardiovascular diseases and other diseases sharing common risk factors". Report 1986-1987, National Public Health Institute, Helsinki 1988.

25 WHO Monica Project. WHO MONICA Project: risk factors. Int J Epidemiol 1989;18:46-55. 